\title{
Research on the Management of Tourism Scenic Spots and Its Countermeasures
}

\author{
Su Aihua, Chen Nan \\ Nanchang Institute of Science \& Technology, Nanchang, Jiangxi, 330013
}

\begin{abstract}
As the tourism industry core elements of the tourist attractions, at this stage is the development of Chinese tourism industry in the weak link. For a long time, due to the complexity of the tourist attraction system, the administrative pattern of many administrative departments, coupled with the widespread location constraints, weak infrastructure, lack of capital investment and lack of talent plaque problems, making Chinese tourist attractions professional management level is low, the market It is difficult to meet the requirements of local economic and social development and people 's growing material and cultural needs of life. It is difficult to adapt to the socialist market economic system reform and the trend of tourism industry development, it is difficult to meet the requirements of local economic and social development and people' s growing material and cultural needs.
\end{abstract}

Keywords: Scenic Spots, Countermeasures, Tourism Management

\section{Introduction}

Tourist attractions are the core elements of the tourism industry, but at this stage it is the weak link in the development of Chinese tourism industry. Its development level, and the rapid expansion of the tourism industry and the local economic and social development of the expectations of the area is not suited to the conflict is more prominent. The rapid growth of Chinese tourism industry, especially the strong momentum of the development of holiday tourism, put forward higher requirements for the development of tourist attractions, requiring a greater number of tourist attractions, greater capacity, more categories, better 
distribution, higher matching, Order better, better quality, the formation of a more powerful supply system of tourism products. With the development of the western region, the western region has high expectations for the development of tourism. It is eager to develop the tourism resources as soon as possible to promote the local economic development and bring the local people out of poverty. In the tourism industry to adapt to the expansion and development needs of local areas, tourist attractions face the problem is how to achieve their own faster, better and greater development. However, for a long time, due to the complexity of the tourist attraction system, the administrative pattern of many administrative areas, coupled with the widespread location constraints, weak infrastructure, lack of capital investment and lack of talent plaque, making Chinese tourist attractions professional management level low , Poor adaptability of the market economy, lack of sustainable development potential, it is difficult to adapt to the socialist market economic system reform and the development trend of the tourism industry, it is difficult to meet the local economic and social development requirements and people's growing material and cultural life needs. At present, tourist attractions have become the weak point of the industrial system, the focus of tourism development, local government point of view, the local people rely on the point and the focus of social concern.

\section{Management Status of Tourist Attractions in China}

Chinese vast territory, beautiful mountains and rivers, has a long history, many nationalities, rich and varied tourism resources. According to the classification of tourism resources in the national standards of tourism resources classification, investigation and evaluation, there are 8 types, 31 sub-categories and 155 basic types of tourism resources in China. Relying on rich tourism resources, China has developed a variety of tourism products, currently launched in the market of products, both tourism-based tourism products, there are holiday-type tourism products, as well as various types of special tourism products, tourism Product type diversity is one of the most basic characteristics of tourist attractions.

At present, the macro-management pattern of tourist attractions in China can be simply summarized as a multi-government, institutional chaos. Chinese tourist attractions are under the management of more than 10 different government departments, scenic areas, nature reserves, forest parks and other units, both their own resources to protect the functions, but also the organization of production, economic development, employment and community management Functions. The management of scenic resources and cultural relics resources in China is exercised by all levels and the relevant administrative departments. According to Chinese current administrative system, all kinds of scenic resources and cultural relics resources are still owned by the construction, forestry, environmental protection, culture, heritage, religion, marine, geology, tourism and other departments to exercise management rights, according to their scientific value, historical and cultural value, Aesthetic value and geographical scope divided into national, provincial and county levels, respectively, by the relevant administrative 
departments at all levels of management. (Such as scenic spots, national forest parks, nature reserves management committees (or the Authority), cultural relics management committee (or the text of the management), as a national resource owners on behalf of the unified management of the implementation of the right to .

The vast majority of the current tourist attractions is the preparation of institutions, staff wait for a year to eat the financial rice, the lack of efficient development and rational use of funds. With the gradual deepening of Chinese economic system reform, many scenic spots are actively changing, active management system reform, seeking further survival and development, but the management mechanism of backwardness and conservative ideas make many scenic management system reform and effectiveness Not obvious. For example, although some scenic spots in the form of clear for the enterprise, but with a very strong government imprint, in the actual work did not dilute the functions of the government, this system reform is the reform of the fur and did not seize the essence.

Some scenic tourist order disorder, service dysfunction, has a certain security risk, the rights and interests of tourists are not effectively guaranteed. The reasons here are mainly from two aspects: First, some scenic areas and even subcontracting the implementation of sub-contractors, owners of their own line of business, the lack of co-ordination, bringing the order of the chaos management area. Second, some operators of scenic spots quick success, only focus on the development of new projects and neglect the construction of internal service facilities.

The problems of resources and environmental protection of tourist attractions in our country are manifested in the serious disruptive construction of tourist attractions and the outstanding urbanization of natural scenic spots. Some quality is not high companies involved in the development of tourism resources, so that the construction of vulgarization of the scenic area, the destruction of tourism resources is very large and difficult to restore. Many tourist attractions have different degrees of resource degradation, there are traffic caused by the reasons, but more mainly due to poor protection caused. In addition, the scenic area of the problem of environmental pollution is also very serious, due to poor domestic waste disposal, environmental protection technology, but customs, resulting in poor sanitation area, the resulting pollution problems prevalent.

The state financial resources for the protection of cultural relics are very limited financial resources, relative to the development of tourist attractions only a drop in the bucket. Management funds and staff wages partly depend on financial appropriations, partly by self-financing, some fully self-supporting. In this case, most places can barely maintain the status quo and livelihood of workers, not to mention effective protection and active construction. Even the scenic area residents and workers forced livelihoods and deforestation, hunting animal behavior, destruction of resources and the environment phenomenon despite repeated prohibitions. In the old scenic management system, the precious resources become a financial burden, so holding the gold bowl to eat. 
In many scenic spots and cultural relics, due to the fragmentation and the separation of government and enterprises, regardless of political affairs, government agencies and the old state-owned enterprises have been reflected in the various drawbacks; L. In the management of reception, is basically waiting for customers, rarely take the initiative to promote promotion: in the economic balance of payments, financial allocation of units and income, and some slight surplus, the majority of income exceeds: in the labor and personnel system, bloated, redundant staff: In the distribution system, the death of wages, "big pot", the prevalence of egalitarianism. This kind of management system and management mechanism lead to the results, or cause the idle and waste of cultural relics resources, or bring the development and operation of landscape tourism in the disorder, inefficiency and even damage, seriously plaguing the protection of resources and environment and local tourism economy development of.

\section{Analysis on the Reform Mode of Scenic Area Management}

Ownership of enterprises and the right to operate one, this is the basic characteristics of the planned economy system and one of the most important drawbacks. Since 1978, Chinese economic system reform, ownership and management rights of the enterprise system have been broken, replaced by the separation of ownership and management of the modern enterprise system. However, due to tourism resources is the state of all the special public resources, scenic cause is the country's social welfare undertakings, so many people believe that direct management of tourist attractions by the state most able to reflect the public interest of society as a whole. Until now, the vast majority of tourist attractions in China is still the implementation of the national direct management model. From a practical point of view, this business model defects are obvious. In this business model, the state commitment to tourism scenic spots at all levels of specific business decisions and all operational risks, scenic management committee on behalf of the State free use of resources, because they do not have to bear the consequences of profit and loss, so the lack of interest-driven and competitive pressures, The quality of resources is difficult to operate in accordance with the law of market value, the result will inevitably lead to the scenic resources are not reasonable protection and utilization, so that their economic value is not fully reflected in the resulting low operating efficiency of scenic spots, Management backward, the general loss situation, has seriously hampered the development of Chinese scenic areas. In promoting the national economy market-oriented reform of the general trend, the implementation of market-oriented tourism scenic spot is imperative.

Listed joint-stock enterprise business model is characterized by the implementation of enterprise-type tourist attractions management, and its main business is a joint-stock listed companies. Local governments set up scenic management committee, as the government agencies, responsible for unified management of scenic spots. Scenic Spot Management Committee is responsible for tourism protection, listed company is responsible for the development and 
utilization of tourism resources. The scenic area management committee is responsible for the tourism development and utilization of the listed company. The scenic area management committee is responsible for the scenic area management committee, the franchise fees paid by the scenic area franchise fees directly entrusted to the listed company by the scenic area management committee.

Under the state-owned enterprise group's integrated development and management model is characterized by the implementation of enterprise-type tourist attractions management, its main business is wholly state-owned enterprises, but the local government under the state-owned companies. These scenic spots are operated by the state-owned tourist attractions company. In this model, the ownership of the scenic area is separated from the management right, but the resource exploitation right and the protection right are unified. Scenic areas of the ownership of the government, tourism management by the stateowned scenic area business enterprises in charge; scenic area is responsible for the development of scenic resources, but also responsible for the protection of scenic resources. The advantage of this model is the ability to fully integrate the resources of various tourist attractions in accordance with the needs of the tourism market, through integrated development, and comprehensively promote the development of local tourist attractions. China to take this model of scenic spots in Shaanxi Huaqing Pool, Huashan area, Hainan Tianya Haijiao scenic spots and Guangxi Guilin Seven Star Park and other scenic spots. To the effective protection and rational use of the principle of organic integration, according to the nature of various types of scenic spots, different situations to determine different development and management model, to prevent uniformity. In general, developed and has a considerable size of the mature area, in the existing management system based on the reform and innovation, to achieve separation of government and enterprises, ownership and management of the separation; and for many not yet developed, especially the development conditions The introduction of foreign capital, technology, management, speed up the development and construction of scenic spots, improve the management level of the scenic spot, the introduction of foreign capital, technology, management, to speed up the development and construction of scenic spots, improve scenic management level.

\section{Conclusion}

However, the development of the road is not smooth sailing, institutional collision is difficult to avoid. Because of the public resources protection and development of awareness of the different institutional barriers have become a matter of concern to the industry. Based on the objective reality of "the core of tourism in the scenic area and the key of development in the system", the management system of tourist attractions in our country has reached the critical moment. The management system reform and mechanism innovation of tourism 
scenic spot gradually become the urgent requirement and primary task of the development of tourism in our country.

\section{References}

[1] Tao Wei. Study on Sustainable Tourism Development of Chinese "World Heritage". Tourism Tribune, 5(2), pp. 31-33, 2005.

[2] Xu Songling. How to understand the tourism resources of scenic tourism management-Comment on the "scenic spots listed on the stock market" controversy . Journal of Tourism, 3(6), pp. 27-29, 2000.

[3] Zhang Lingyun. The tourism scenic spots listed on the issue of several companies . Journal of Tourism, 11(6), pp. 97-99, 2003.

[4] Peng Decheng. Study on Capital Market Strategy of Tourism Resources Development in Central and Western China. Tourism Tribune, 2(6), pp. 103-106, 2002.

[5] Daoxue Feng. Analysis of Tourism Listed Companies' Operation. Tourism Tribune, 1(8), pp. 52-53, 2000. 